\title{
相対的海水準の急激な上昇イベントが示唆する 養老断層系の完新世活動
}

\section{一濃尾平野西縁におけるボーリングコアの解析からー}

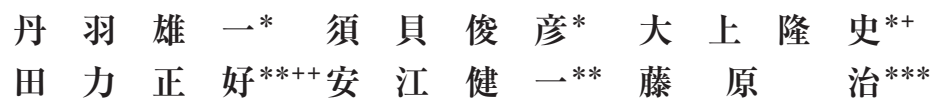

\section{Holocene Activity of the Yoro Fault System, Western Margin of the Nobi Plain, Central Japan, Detected by Rapid Relative Sea-level Rise Recorded in 20 m-long Drilling Cores}

\author{
Yuichi NIWA* , Toshihiko SUGAI*, Takashi OGAMI*+, \\ Masayoshi TAJIKARA ${ }^{* *+}$, Ken-ichi YASUE ${ }^{* *}$ and Osamu FUJIWARA***
}

\begin{abstract}
A 6000-year history of relative sea-level change on the western Nobi plain, at the footwall side of the Yoro fault, was reconstructed from three drilling cores based on analyses of sedimentary facies, grain-size distributions and electrical conductivity (EC), as well as $20{ }^{14} \mathrm{C}$ age determination. The Yoro fault comprises the northern part of the Yoro fault system. These cores show a prograding delta sequence. Two intervals characterized by fine deposits, mainly composed of fine sand, and high EC value are identified in sandy delta front deposits showing a general coarsening upward sequence. In synchronous with these changes in the delta front, a rapid rise of EC value is recognized in the abandoned channel fill deposits on the delta plain. These data suggest that temporal sea-level rise events occurred during the progradation process of the delta system. A probable cause of these events is coseismic subsidence. These subsidence events are dated at around 5600-4700 cal BP and 4600-3800 cal BP, respectively.

The above-mentioned subsidence events broadly correspond with previously known faulting events at the Kuwana fault to the south of the Yoro fault. Evidence for the faulting of the Yoro and Kuwana faults associated with two historical earthquakes (AD 745 and AD 1586) accompanied by coseismic subsidence and synchronicity of the subsidence events identified in this study and faulting events at the Kuwana faults suggest that subsidence events identified in this study are caused by faulting at the Yoro fault. These results are consistent with the notion that the Yoro and Kuwana faults comprise a behavioral segment in the Yoro fault system.
\end{abstract}

\footnotetext{
* 東京大学大学院新領域創成科学研究科自然環境学専攻

** 日本原子力研究開発機構東濃地科学センター

*** 産業技術総合研究所活断層・地震研究センター

+ 現所属 : 中央大学理工学部

++ 現所属 : 地震予知総合研究振興会地震調查研究センター

* Department of Natural Environmental Studies, Graduate School of Frontier Science, The University of Tokyo

** Tono Geoscience Center, Japan Atomic Energy Agency

*** Active Fault and Earthquake Research Center, National Institute of Advanced Industrial Science and Technology

+ Present address: Faculty of Science and Engineering, Chuo University

${ }^{++}$Present address: Earthquake Research Center, Association for the Development of Earthquake Prediction
} 
Key words : coseismic subsidence, ${ }^{14} \mathrm{C}-\mathrm{AMS}$, relative sea-level rise, Nobi plain, drilling core, Yoro Fault System

キーワード：地震沈降， ${ }^{14} \mathrm{C}$ 年代，相対的海水準上昇，濃尾平野，ボーリングコア，養老断層系

\section{I. はじめに}

日本の活断層を震源とする大地震の長期評価の ために，断層直上（オンフォールト）で数多くの トレンチ調査が行われ, 多数のイベント認定と年 代測定が行われ，それらの成果がまとめられてい る（地震調查研究推進本部, 2010)。しかし, 例 えば堆積速度の大きな平野のようにトレンチ調査 の適用が困難な場所もある。そのような場所で は，断層から離れた場所（オフフォールト）にお いて，過去の大地震発生に関連したさまざまな 地表および地下浅部の現象を手掛かりに大地震発 生の時系列を解明する必要がある（山崎ほか, 2004)。

養老断層系は濃尾平野の西縁を画する活断層系 で，北から養老断層・桑名断層・四日市断層の三 条の逆断層からなり, その全長は約 $55 \mathrm{~km}$ に達 する（活断層研究会, 1991; 須貝ほか, 1999; 池田 ほか, 2002; 図 1)。この断層系の活動履歴や活動 セグメント（固有地震を伴う活動を繰り返す断層の 最小単位 behavioral segment; MaCalpin, 1996) 区分を明らかにすることは，この断層系から発生 する地震の再来間隔と規模を推定し, 濃尾平野周 辺の地震防災を検討する上でも重要である。

養老断層は西側の養老山地と東側の濃尾平野の 地形境界部に位置する。養老山地は主に中・古生 界の堆積岩類で構成される（高田ほか, 1979）。 一方, 濃尾平野の地下には約 $1500 \mathrm{~m}$ 以上の層厚 を有する新第三系第四系が存在することが知ら れている（須貝ほか, 1998）。このように，養老 断層は濃尾平野西縁地域の地形・地質構造の境界 をなす主要な逆断層である（桑原, 1968; Ishiyama et al., 2007)。同断層の歴史時代の活動時期 に関しては, 群列ボーリング調査に基づいて, $\mathrm{AD} 745$ 年天平地震（宇佐美, 1996）と $\mathrm{AD} 1586$ 年天正地震（飯田, 1987）の震源断層である可能
性が示されたほか，完新世における平均活動間隔 は 1500 年程度と見積もられている（須貝ほか, 1999)。

桑名断層と四日市断層は, 中～後期更新世の段 丘面を変位させており（貝塚, 1950; 松田ほか, 1977; 岡田, 1979; 活断層研究会, 1980, 1991; 大田・寒川, 1984; 吉田, 1984), 完新世段丘にも 変位を与えていることが指摘されている（粟田・ 吉田, 1991)。養老断層から連続する桑名断層も $\mathrm{AD} 745$ 年天平地震（宇佐美, 1996）と $\mathrm{AD} 1586$ 年天正地震（飯田, 1987）の際に活動した可能性 （須貝ほか, 1998）に加え，4本のボーリングコア （図 1 の YR200，YR275，YR350，YR800）を使っ た内湾堆積物の堆積速度变化の詳細な解析によっ て, 平野を沈降させる断層活動が約 6600 年前, 約 5700 年前, 約 4000 年前, 約 3600 年前, 約 2100 年前（いずれも暦年）の合計 5 回推定され た（鳴橋ほか, 2004; Naruhashi et al., 2008）。四 日市断層は, 桑名断層とは約 $5 \mathrm{~km}$ 右ステップし て連続する関係にある（図 1）が，過去 7000 年 間の上下変位の累積パターンと最近 3 回の断層 活動時期・上下変位量は, 桑名断層とほぼ一致す る（大上・須貝, 2006)。

養老断層系下盤側に位置する濃尾平野は，世界 最大級の削剥速度をもつ中部山岳地域 (Ohmori, 1983）から流下する木曽三川による砕屑物供給 量が非常に多く, 平野の地下には完新統が厚く堆 積している。このような地域でのオンフォールト 古地震学的検討は, 河川堆積物の被覆が厚いこと や，断層直上（オンフォールト）では撓曲変位が 中心であることから，断層イベントの認定が難し い。このような場合, より古い過去の活断層の活 動履歴を解明するための方法として, 平野の地下 に埋もれた地層から, 間欠的沈降のようなオフ フォールトイベント (MaCalpin and Nelson, 1996）を示す層相変化を読み出し，その年代を 


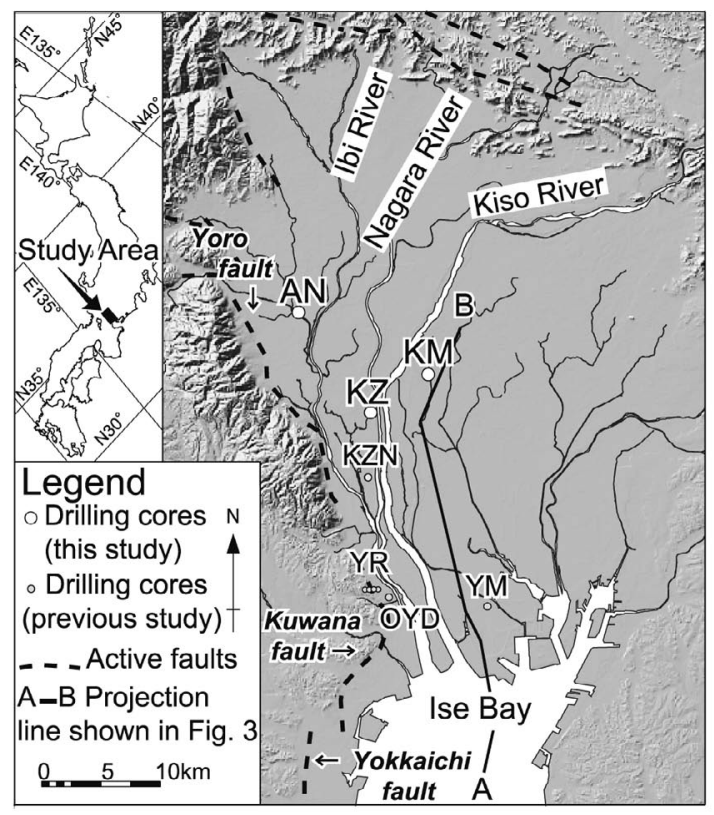

図 1 位置図.

陰影図の作成に際しては国土地理院発行の $50 \mathrm{~m}$ メッ シュ数值標高地図を使用した. YM(弥富) コア, OYD (大 山田）コア，KZN（海津苑）コアは丹羽ほか（2009）, YR（東から汰上 No. 200, 汰上 No. 275, 汰上 No. 350, 汰上 No. 800）コアは鳴橋ほか (2004), Naruhashi et al. (2008) による.

Fig. 1 Index map.

Shaded relief map of study area was prepared using a 50-m mesh digital elevation model (DEM) from Geographical Survey Institute of Japan. Core YM, OYD, and KZN are from Niwa et al. (2009). Cores YR (YR200, YR275, YR350, and YR800) are from Naruhashi et al. (2004, 2008).

測定することがあげられる。このような方法は, 沈降速度の速い堆積平野縁辺の活断層や堆積平野 下の伏在活断層の活動履歴を明らかにする上で大 変重要であり, 養老断層系でも完新世における活 動履歴の推定に活用されている。丹羽ほか (2009) では，濃尾平野南部で掘削された 3 本の ボーリングコア（図 1 の YM，OYD，KZN）の 層相解析, 電気伝導度から平野の沈降イベントが 検出され, ${ }^{14} \mathrm{C}$ 年代測定值から 2 回の歴史地震時の 養老断層の活動による沈降イベントの可能性が示 された。桑名断層については前述のように, 鳴橋 ほか (2004), Naruhashi et al. (2008) によって
過去 7000 ～ 2000 年前の間に平野を沈降させる 断層活動が 5 回推定された。

本研究では, 養老断層の沈降側の濃尾平野西部 から得られたボーリングコア（図 1 の KZ，KM， AN）の解析からオフフォールトイベントの検出 とそれらの時期の特定を試み，同断層の歴史時代 以前の活動履歴を推定する。また，その結果を桑 名断層の活動履歴と比較することによって，両断 層が 1 つの活動セグメントを構成している可能 性を検討する。

用いたコアは，木曾川デルタの前進によって形 成された地層から構成され（山口ほか, 2003; 大上 ほか, 2009)，丹羽ほか（2009）で用いた 3 本のコ アよりも上流側に位置することから，堆積物中に は有史以前の木曽川デルタの形成過程と養老断層 の活動による沈降の特徵（浅海域の一時的な水深 増加化および陸上氾濫原の海面下への沈水に伴う 層相変化）が記録されていることが期待される。

\section{II. 濃尾平野西部の沖積層層序とコア試料}

\section{1）沖積層層序}

濃尾平野は養老断層系を主体とする構造運動に より西方へ傾動しながら沈降する傾動盆地であり (桑原, 1968), その傾動速度は 90 万年前以降約 $0.86 \times 10^{-4} / \mathrm{kyr}$ ，沈降速度は最大約 $1 \mathrm{~m} / \mathrm{kyr}$ と 見積もられている（須貝・杉山, 1999）。加えて, 木曽川をはじめとする河川による活発な土砂供給 のため，濃尾平野には，沖積層が最大で約 $50 \mathrm{~m}$ 以上堆積している（山口ほか, 2006a）。

調査地域の沖積層の層序は, 大半が木曾川デ ルタの堆積物であり，その層序と層相は井関 (1962), 海津 (1992), 山口ほか (2003), 大上 ほか（2009）などによって研究され, 堆積環境 とデルタの形成プロセスが復元されてきた。山口 ほか（2003）は，海津コア（以下 KZと略記す る）と大山田コア（OYD；図 1) を用いて堆積 構造や粒度の特徵によって, この地域の沖積層を 下位から網状河川堆積物である沖積層基底礫層 (BG), 蛇行河川〜感潮帯堆積物である下部砂泥 層 (LSM)，プロデルタ堆積物である中部泥層 $(\mathrm{MM})$ ，デルタフロント堆積物である上部砂層 
表 1 既往研究（山口ほか, 2003, 2006b）の堆積相区分.

Table 1 Unit classification of middle to late Holocene in the Kiso River delta (Yamaguchi et al., 2003, 2006b).

\begin{tabular}{c|l|l}
\hline Classification & \multicolumn{1}{|c}{ Lithofacies } & \multicolumn{1}{|c}{ Sedimentary Environments } \\
\hline TSM & Alternation of Sand/Mud & $\begin{array}{l}\text { Delta Plain/Flood Plain } \\
\text { (Channel, Abandoned Channel Fill, Natural Levee, } \\
\text { Back Swamp, Tidal Flat) }\end{array}$ \\
\hline US & $\begin{array}{l}\text { Well Sorted Sand } \\
\text { Coarsing Upward Silt - Sand }\end{array}$ & Delta Front \\
\hline MM & Mussive Mud & Prodelta \\
\hline
\end{tabular}

表 2 コアの情報.

Table 2 Specifications of cores.

\begin{tabular}{|c|c|c|c|c|c|c|}
\hline Core name & $\begin{array}{c}\text { Drilled } \\
\text { year }\end{array}$ & $\begin{array}{l}\text { Ground level } \\
\text { (m asl) }\end{array}$ & $\begin{array}{c}\text { Drilling } \\
\operatorname{depth}(\mathrm{m})\end{array}$ & $\begin{array}{c}\text { Distance from } \\
\text { the Yoro fault }(\mathrm{km})\end{array}$ & \multicolumn{2}{|c|}{ Latitude and Longitude } \\
\hline Kaizu (KZ) & 1998 & 1.90 & 601.0 & 5 & $35^{\circ} 13^{\prime} 31^{\prime \prime} \mathrm{N}$ & $136^{\circ} 40^{\prime} 15^{\prime \prime} \mathrm{E}$ \\
\hline Kammaki (KM) & 2004 & 3.25 & 40.0 & 10 & $35^{\circ} 14^{\prime} 33^{\prime \prime} \mathrm{N}$ & $136^{\circ} 43^{\prime} 29^{\prime \prime} \mathrm{E}$ \\
\hline Asanishi (AN) & 2004 & 3.30 & 44.3 & 5 & $35^{\circ} 18^{\prime} 45^{\prime \prime} \mathrm{N}$ & $136^{\circ} 34^{\prime} 58^{\prime \prime} \mathrm{E}$ \\
\hline
\end{tabular}

(US), 現成の氾濫原堆積物である最上部層 (TSM) に区分した。大上ほか（2009）はさら に，コアデータを追加して，過去約 6500 年間に わたるデルタの前進過程を明らかにした。これら の研究によると，完新世木曽川デルタの平均的な 前進速度は $5 \sim 10 \mathrm{~m} / \mathrm{yr}$ と見積もられている。 表 1 に本研究で対象とする中部泥層 (MM) 以浅 に対して山口ほか $(2003,2006 b)$ で報告されて いる調查地域周辺の堆積ユニット区分を示す。

\section{2) ボーリングコア試料}

研究対象としたコアは, 上記の海津コアに上 牧コア $(\mathrm{KM})$, 浅西コア（AN）を加えた 3 本で ある（図 1)。これらのコアは養老断層の下盤（沈 降）側かつ中部泥層（MM）の分布域（山口ほか, 2006a）に位置する。また，前述のように，堆積 物中にはより古い時代の木曽川デルタの形成過程 と養老断層の活動による沈降の特徵が記録されて いることが期待される。各コアの掘削地点の標高 と掘削深度, 掘削年, 養老断層地表トレース（活 断層研究会, 1991; 須貝ほか, 1999; Ishiyama et $a l ., 2007 ）$ からの距離，緯度経度を表 2 に示す。

\section{III. 分析方法}

上述した 3 本のコアのそれぞれ深度 $20 \mathrm{~m}$ 以浅 の部分を対象に, 岩相記載, 粒度分析, 電気伝導 度（EC） 測定， ${ }^{14} \mathrm{C}$ 年代測定を行った。

岩相記載は 5 分の 1 スケールで行った。その 際, 粒度, 堆積構造, 生物擾乱, 貝化石や植物片 の有無を記載した。粒度分析は各コアの深度方向 $5 \sim 20 \mathrm{~cm}$ 間隔でレーザー回折散乱式粒度分析装 置（SALD-3000S；島津製作所）を用いて行っ た。分析用サンプルは, 生痕部分を避け，代表的 な岩相を示すと思われる部分から採取した。 KZ コアの粒度デー夕は，同様の条件で測定された山 口ほか（2005）を用いた。

$\mathrm{EC}$ 測定はコア深度方向 $5 \sim 200 \mathrm{~cm}$ 間隔で $\mathrm{EC} メ ー タ （ \mathrm{ES}-51$; 堀場製作所）を用いて行っ た。 EC 測定用の試料の作成方法は, 横山・佐藤 （1987）を参考にして， $110^{\circ} \mathrm{C} て ゙ ~ 48$ 時間以上乾燥 させた後に粉砕した試料 $5 \mathrm{~g}$ に蒸留水 $60 \mathrm{ml}$ を加 えて混濁水をつくった。混濁水を攪拌して 1 時 間後，5 日後， 7 日後に測定を行い，5 日後と 7 
表 $3{ }^{14} \mathrm{C}$ 年代測定結果.

Table $3{ }^{14} \mathrm{C}$ age determination data.

\begin{tabular}{rllrrrr}
\hline Core & Lab code & Material & $\begin{array}{c}\text { depth } \\
(\mathrm{m})\end{array}$ & $\begin{array}{c}\text { Altitude } \\
(\mathrm{m} \text { TP })\end{array}$ & $\begin{array}{c}\text { Conventional } \\
\text { age }(\text { yrs BP })\end{array}$ & $\begin{array}{c}\text { Calibrated age } \\
(2 \text { ocal BP })\end{array}$ \\
\hline AN & JNC-6288 & plant material & 4.27 & -0.97 & $1289 \pm 50$ & $1121-1298$ \\
AN & JNC-6289 & plant material & 6.87 & -3.57 & $2052 \pm 51$ & $1896-2143$ \\
AN & JNC-7457 & shell & 11.13 & -7.83 & $4330 \pm 50$ & $4305-4615$ \\
AN & JNC-6290 & shell & 11.36 & -8.06 & $4298 \pm 55$ & $4242-4572$ \\
AN & JNC-6291 & shell & 14.18 & -10.88 & $5103 \pm 60$ & $5313-5576$ \\
AN & JNC-6292 & shell & 18.05 & -14.75 & $6419 \pm 61$ & $6734-7086$ \\
\hline${ }^{* 1} \mathrm{KM}$ & JNC-7475 & plant material & 5.03 & -1.78 & $1220 \pm 50$ & $1053-1277$ \\
${ }^{* 1} \mathrm{KM}$ & JNC-6298 & plant material & 7.90 & -4.65 & $3759 \pm 57$ & $3965-4297$ \\
${ }^{* 1} \mathrm{KM}$ & JNC-6299 & shell & 10.45 & -7.20 & $4526 \pm 55$ & $4555-4853$ \\
${ }^{* 1} \mathrm{KM}$ & JNC-6300 & shell & 13.95 & -10.70 & $4657 \pm 60$ & $4764-5059$ \\
${ }^{* 1} \mathrm{KM}$ & JNC-6301 & shell & 17.14 & -13.89 & $5128 \pm 60$ & $5320-5592$ \\
\hline${ }^{* 2} \mathrm{KZ}$ & Beta-128275 & organic sediment & 5.65 & -3.75 & $2170 \pm 70$ & $2002-2333$ \\
${ }^{* 2} \mathrm{KZ}$ & JNC-3241 & wood & 6.15 & -4.25 & $3153 \pm 61$ & $3214-3483$ \\
${ }^{* 2} \mathrm{KZ}$ & Beta-123387 & wood & 9.20 & -7.30 & $3170 \pm 70$ & $3240-3562$ \\
${ }^{* 2} \mathrm{KZ}$ & JNC-3242 & wood & 10.82 & -8.92 & $3629 \pm 67$ & $3821-4101$ \\
${ }^{* 2} \mathrm{KZ}$ & JNC-3243 & wood & 12.10 & -10.20 & $3645 \pm 62$ & $3828-4151$ \\
${ }^{* 2} \mathrm{KZ}$ & JNC-3244 & wood & 13.93 & -12.03 & $3707 \pm 66$ & $3868-4241$ \\
${ }^{* 2} \mathrm{KZ}$ & JNC-3246 & wood & 16.86 & -14.96 & $3683 \pm 64$ & $3843-4159$ \\
${ }^{* 2} \mathrm{KZ}$ & Beta-123388 & organic sediment & 17.80 & -15.90 & $4370 \pm 50$ & $4839-5056$ \\
${ }^{* 2} \mathrm{KZ}$ & JNC-3247 & shell & 19.80 & -17.90 & $4067 \pm 62$ & $3907-4294$ \\
\hline
\end{tabular}

$* 1{ }^{14} \mathrm{C}$ ages by Ogami et al. (2009)

$* 2{ }^{14} \mathrm{C}$ ages by Yamaguchi et al. (2003)

日後で值がほとんど変化しないことを確認し，7 日後のデー夕を用いた。KZ コアについては，同 様の方法で測定された山口ほか（2001）の EC デー夕を用いた。

${ }^{14} \mathrm{C}$ 年代測定は $\mathrm{AN} コ ア に$ 対して合計 6 試料を 加速器質量分析 (AMS) 法によって日本原子力 研究開発機構で行った。得られた年代值は CALIB5.0（Stuiver and Reimer, 1993）で陸源物質 に対しては INTCAL04（Reimer et al., 2004）を, 貝化石に対しては MARINE04 (Hughen et al., 2004）をそれぞれ用いて暦年較正した。調査地 域のローカルリザーバ効果が現時点では不明なた め, 海洋表層水の平均值である 400 年で貝化石 の年代值を補正した。また，KZコアについては， 山口ほか（2003）が報告した 9 個の年代值を, KM コアについては，大上ほか（2009）が報告
した 5 個の年代值を用い，同様の方法で暦年較 正した。 ${ }^{14} \mathrm{C}$ 年代測定データを表 3 に示す。

\section{IV. 堆積相区分と堆積環境の推定}

各コアについて堆積相を区分し，堆積環境を推 定した。ECから推定される堆積環境は, 珪藻群 集組成に基づく古環境との対応を検討した内園・ 森（2004）を参考に，0.6 mS/cm 以下であれば 淡水性，それ以上であれば汽水〜海水性と堆積環 境を推定した。図 2 に柱状図，中央粒径，淘汰 度， $\mathrm{EC},{ }^{14} \mathrm{C}$ 年代值の分析結果を示す。

堆積相 1 : 本相は, $\mathrm{KM}$ コアの深度 $18.00 \mathrm{~m}$ 以 深，AN コアの深度 $17.80 \mathrm{~m}$ 以深に認められる。 この地層は，貝化石を含む泥層からなり，中央粒 径と淘汰度はそれぞれ，KM コアで $5.6 \sim 6.4 \phi$, $1.9 \sim 2.1, \mathrm{AN} コ$ ア $6.0 \sim 7.0 \phi, 1.9 \sim 2.0$ 

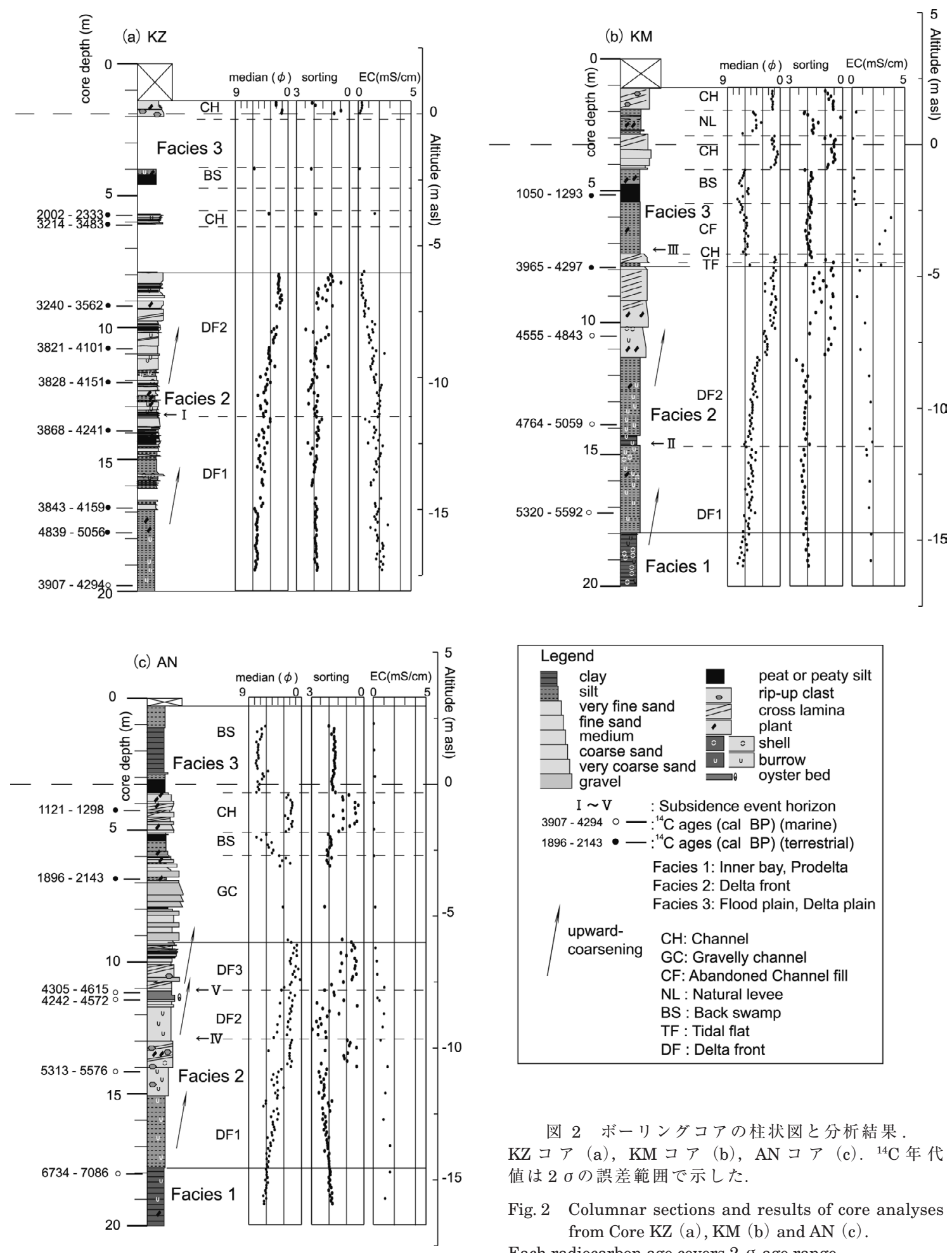

図 2 ボーリングコアの柱状図と分析結果.

$\mathrm{KZ} コ ア(\mathrm{a}), \mathrm{KM} コ ア(\mathrm{~b}), \mathrm{AN} コ ア(\mathrm{c}),{ }^{14} \mathrm{C}$ 年 代 值は $2 \sigma$ の誤差範囲で示した.

Fig. 2 Columnar sections and results of core analyses from Core KZ (a), KM (b) and AN (c).

Each radiocarbon age covers $2 \sigma$ age range. 
である。 $\mathrm{EC}$ は $\mathrm{KM}$ コアで $1.5 \mathrm{mS} / \mathrm{cm}$ 以上， $\mathrm{AN}$ コアで $1.1 \mathrm{mS} / \mathrm{cm}$ 以上を示す。 ${ }^{14} \mathrm{C}$ 年代值は, AN コアの深度 $18.05 \mathrm{~m}$ の貝化石からは 6734$7086 \mathrm{cal} \mathrm{BP}$ の較正年代が得られた。

細粒で均質な粒子で構成されること，貝化石を 含み, EC が海水成を示す高值であること, 後述 のデルタフロント堆積物に覆われることから, 内 湾・プロデルタ堆積物と解釈される。

堆積相 2 : 本相は, $\mathrm{KZ}$ コアの $20.00 \sim 7.90 \mathrm{~m}$, $\mathrm{KM}$ コアの深度 $18.00 \sim 7.89 \mathrm{~m}, \mathrm{AN}$ コアの深 度 $17.80 \sim 9.19 \mathrm{~m}$ に認められる。この地層は上 方粗粒化を示す砂質シルト〜中粒砂層からなる。 $\mathrm{KM}$ コアと AN コアともに下位層との境界は漸移 的である。各コアともに上方粗粒化に伴って中央 粒径が $6 \phi$ から $1 \phi$ へと, 淘汰度は $1.8 \sim 2.2$ か ら 0.5 へと変化する。下部〜中部で生物擾乱痕が 多く, 中部〜上部では植物片, 斜交層理が認めら れる。AN コアではシルトの偽礫が認められる。 $\mathrm{KZ}$ コアの深度 $13.43 \mathrm{~m}$ （図 2 の境界面 I ), KM コアの深度 $14.70 \mathrm{~m}$ (図 2 の境界面 II ), $\mathrm{AN}$ コ アの深度 $13.00 \mathrm{~m}$ （図 2 の境界面 IV ）と深度 $11.10 \mathrm{~m}$ （図 2 の境界面 V) を挟んでそれぞれ一 時的な細粒化が認められる。それぞれの境界面を 挟んで中央粒径は $3.0 \phi$ から $4.2 \phi$ (境界面 I ), $4.8 \phi$ から $6.1 \phi$ (境界面 II ), $1.6 \phi$ から $4.7 \phi$

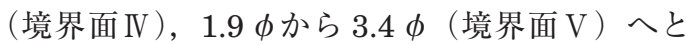
それぞれ変化する。

$\mathrm{EC}$ は $\mathrm{KZ}$ コアで $0.3 \sim 2.4 \mathrm{mS} / \mathrm{cm}, \mathrm{KM}$ コア

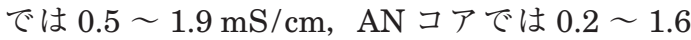
$\mathrm{mS} / \mathrm{cm}$ をそれぞれ示し，各コアとも上方に減少 する傾向が認められる。また，KZコアの境界面 $\mathrm{I}$ を挟んで $0.7 \mathrm{mS} / \mathrm{cm}$ から $1.9 \mathrm{mS} / \mathrm{cm}$ へ, $\mathrm{KM}$ コアの境界面 II を挟んで $1.4 \mathrm{mS} / \mathrm{cm}$ から 1.9 $\mathrm{mS} / \mathrm{cm}$ へ， AN コアの境界面 $\mathrm{IV}$ を挟んで 0.7 $\mathrm{mS} / \mathrm{cm}$ から $0.9 \mathrm{mS} / \mathrm{cm}$ へ, $\mathrm{AN}$ コアの境界面 $\mathrm{V}$ を挟んで $0.4 \mathrm{mS} / \mathrm{cm}$ から $1.1 \mathrm{mS} / \mathrm{cm}$ へとそれ ぞれ一時的に EC が上昇する。

${ }^{14} \mathrm{C}$ 年代值は，KZ コアで 3907-4294 32403562 cal BP，4839-5056 cal BP の較正年代が, KM コアで 5320-5592 3965-4297 cal BP の 較正年代が，AN コア 5313-5576〜 4242-4572 cal BP の較正年代がそれぞれ得られた。

この地層は, 内湾・プロデル夕堆積物を整合的 に覆うこと，上方粗粒化する特徵や EC が下位で 海水成を示す高值で上位に向かって減少すること から，デルタフロント堆積物と解釈される。植物 片が上位ほど増加することは河口からの距離が近 づいたことを示しており，これは上方浅海化とも 関連していると考えられる。本相の堆積年代は, 上流側ほど古く，下流側ほど若い。これらのこと は，本相がデルタフロント堆積物であるという見 解を支持する。

また，KZ コアの深度 $13.43 \mathrm{~m}$ の境界面 I を挟 んだ上方粗粒化する 2 つの堆積ユニットを DF1。 DF2 に細分する。同様に KM コアの深度 14.70 $\mathrm{m}$ の境界面 II を挟んだ上方粗粒化する 2 つの堆

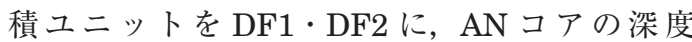
$13.00 \mathrm{~m}$ の境界面 $\mathrm{IV}$ と深度 $11.10 \mathrm{~m}$ の境界面 $\mathrm{V}$ を挟んだ上方粗粒化する 3 つの堆積ユニットを DF1・DF2・DF3 にそれぞれ細分する。これら の成因については後述する。

堆積相 3 : 本相は, $\mathrm{KZ}$ コアの $7.90 \sim 1.40 \mathrm{~m}$, $\mathrm{KM}$ コアの深度 $7.89 \sim 1.13 \mathrm{~m}, \mathrm{AN} コ ア の$ 深度 $9.19 \sim 0.35 \mathrm{~m}$ に認められる。この地層は有機物 を多く含むシルト層と斜交層理の発達する細粒砂 〜中粒砂層を主とする。AN コアでは砂礫層が認 められる。

$\mathrm{EC}$ は $\mathrm{KZ} コ ア の$ 深度 $5.70 \mathrm{~m}$ で $1.6 \mathrm{mS} / \mathrm{cm}$, $\mathrm{KM}$ コアの深度 $7.80 \mathrm{~m}, 7.00 \mathrm{~m}, 6.50 \mathrm{~m}, 6.00 \mathrm{~m}$ で $2.6 \sim 3.7 \mathrm{mS} / \mathrm{cm}$ の高值をそれぞれ示す以外 はすべて $0.6 \mathrm{mS} / \mathrm{cm}$ 以下の低值を示す。

${ }^{14} \mathrm{C}$ 年代は, KZ コアで 2002-2333 cal BP と 3214-3483 cal BP の較正年代が，KM コアで 1050-1293 cal BP の較正年代が， AN コアで 1121-1298 cal BP と 1896-2143 cal BP の較正 年代值がそれぞれ得られた。

デルタフロント堆積物を覆うという層位関係か ら, 氾監原・デルタプレーン堆積物と解釈され る。このことは一部の層準を除いて EC が陸上堆 積を示す低值であることからも支持される。本相 は岩相・EC の特徵から以下の 6 の堆積相に細分 される。 
堆積相 3.1 : 本相は, $\mathrm{KM}$ コアの深度 7.89 $7.74 \mathrm{~m}$ に認められる淘汰の悪いシルト層（中央 粒径 $5.2 \phi$, 淘汰度 2.1$)$ である。 $\mathrm{EC}$ は $2.8 \mathrm{mS}$ / $\mathrm{cm}$ を示す。デルタフロント堆積物を覆うこと, $\mathrm{EC}$ が約 $2.8 \mathrm{mS} / \mathrm{cm}$ で海水の影響を示すことか ら, 干潟堆積物 (TF) の可能性が考えられる。

堆積相 3.2 : 本相は, $\mathrm{KZ}$ コアの梁度 6.08 $5.70 \mathrm{~m}, 2.00 \sim 1.40 \mathrm{~m}, \mathrm{KM}$ コアの深度 7.74 $\sim 7.41 \mathrm{~m}, \quad 4.20 \sim 2.86 \mathrm{~m}, \quad 1.91 \sim 1.13 \mathrm{~m}, \mathrm{AN}$ コアの深度 $5.12 \sim 3.65 \mathrm{~m}$ に認められる細粒砂 ～粗粒砂層（中央粒径 $0.4 \sim 2.8 \phi$, 淘汰度 0.3 〜 1.8) である。砂層は上方細粒化を示し, 斜交 層理やシルトの偽砂が認められる。 $\mathrm{EC}$ は $\mathrm{KZ} コ$ アの深度 $5.70 \mathrm{~m}$ で $1.6 \mathrm{mS} / \mathrm{cm}$ を示す以外は 0.6 $\mathrm{mS} / \mathrm{cm}$ 以下である。上方細粒化を示すことや斜 交層理，シルトの偽礫が認められる，という特徵 から砂質チャネル堆積物 ( $\mathrm{CH}$ ) と解釈される。

堆積相 3.3 : 本相は, AN コアの深度 9.19 $5.94 \mathrm{~m}$ に認められる砂磼層である。上方細粒化 する碟〜極細粒砂層のセットからなる。細磁を主 体とし，植物片を含む砂層を挟む。上方細粒化す る礫〜極細粒砂層のセットからなるという特徴か ら, 礫質チャネル堆積物 (GC) と解釈される。

堆積相 3.4: 本相は, $\mathrm{KZ}$ コアの梁度 4.00 $4.58 \mathrm{~m}, \mathrm{KM}$ コアの梁度 $5.43 \sim 4.20 \mathrm{~m}, \mathrm{AN}$ コ アの深度 $5.94 \sim 5.12 \mathrm{~m}, 3.65 \sim 0.35 \mathrm{~m}$ に認め られる。泥炭層や有機質シルトなど有機物を多く 含む粘土〜シルト層（中央粒径 $4.8 \sim 8.0 \phi$, 淘 汰度 $1.6 \sim 2.2$ ) からなる。 $\mathrm{EC}$ は $0.6 \mathrm{mS} / \mathrm{cm}$ 以 下を示す。有機物を含み，粘土〜シルトを主体と することから, 後背湿地堆積物 (BS) と解釈さ れる。

堆積相 3.5 : 本相は, KM コアの梁度 7.41 $5.43 \mathrm{~m}$ に認められる。砂質チャネル堆積物を覆 う淘汰の悪いシルト層（中央粒径 $5.6 \sim 6.7 \phi$, 淘汰度 $1.8 \sim 2.1$ ） からなり，植物片を含む。硫 黄の析出が肉眼で認められる。 EC は $2.6 \sim 3.7$ $\mathrm{mS} / \mathrm{cm}$ を示す。砂質チャネル堆積物を覆う淘汰 の悪いシルト層という特徵から, 放棄チャネル堆 積物 $(\mathrm{CF})$ と解釈される。下位の砂質チャネル 堆積物との境界（図 2 の境界面吕）を挟んで本
相が高 EC 值を示す原因については後述する。

堆積相 3.6 : 本相は，KM コアの深度 2.86 $1.91 \mathrm{~m}$ に認められる。シルト〜極細粒砂層（中 央粒径 $3.3 \sim 6.1 \phi)$ からなる。淘汰が悪く（淘 汰度 $1.4 \sim 2.2$ ), 深度 $2.20 \mathrm{~m}$ では中央粒径 -0.8 $\phi$ の粗粒砂の薄層を含む。 $\mathrm{EC}$ は $0.6 \mathrm{mS} / \mathrm{cm}$ 以下 を示す。全体的に淘汰が悪く，粒径の鉛直変化が 大きいことから自然堤防堆積物（NL）と解釈さ れる。

\section{V. 考察}

\section{1）木曽川デルタの発達過程}

大上 (2009)，大上ほか (2009) をもとにデル 夕の前進過程を模式的に示してみると（図 3), 木曽川デルタのデルタフロントは, 7000 年前頃 に $\mathrm{AN} コ ア$ 掘削地点を，6000 年前頃には KM コ ア掘削地点を通過し, 約 4000 年前頃には KZコ ア掘削地点まで達したことがわかる。デルタフロ ントが通過した後には, 主に河川の氾濫原で堆積 した地層がデルタを覆った。

各地点のコアには，デルタが前進して浅海環境 から陸へ変化していく過程を反映した地層のサク セッションが期待される。しかし，コアの層相， 粒度, 化学分析結果の鉛直変化抒よび ${ }^{14} \mathrm{C}$ 年代值 からは，木曽川デル夕の前進過程は単純ではな く，丹羽ほか（2009）と同様，デル夕が前進す る途中で相対的海水準の上昇があったことが推定 される。

\section{2）デルタフロント堆積物の一時的な細粒化}

デルタフロント堆積物（US）が全体として上 方粗粒化を示す（図 2）のは，デルタが前進して 掘削地点に河口が近づくにつれて粗粒な堆積物が 増加したためと解釈できる。その過程で一時的に 急激な細粒化と EC の上昇が認められる（KZ コ アの深度 $13.43 \mathrm{~m}$; 図 $2 \mathrm{a}$ の I, KM コアの梁度 $14.70 \mathrm{~m}$; 図 $2 \mathrm{~b}$ の II, $\mathrm{AN}$ コアの深度 $13.00 \mathrm{~m}$; 図 $2 \mathrm{c}$ の $\mathrm{V}, 11.10 \mathrm{~m}$; 図 2c のV)。

デルタフロント堆積物においてこのような急激 な細粒化が起こる原因としては，(1) 掘削地点 が一時的に堆積物の供給源から遠くなった，ある いは（2）洪水で泥の供給が増加したことが考え 


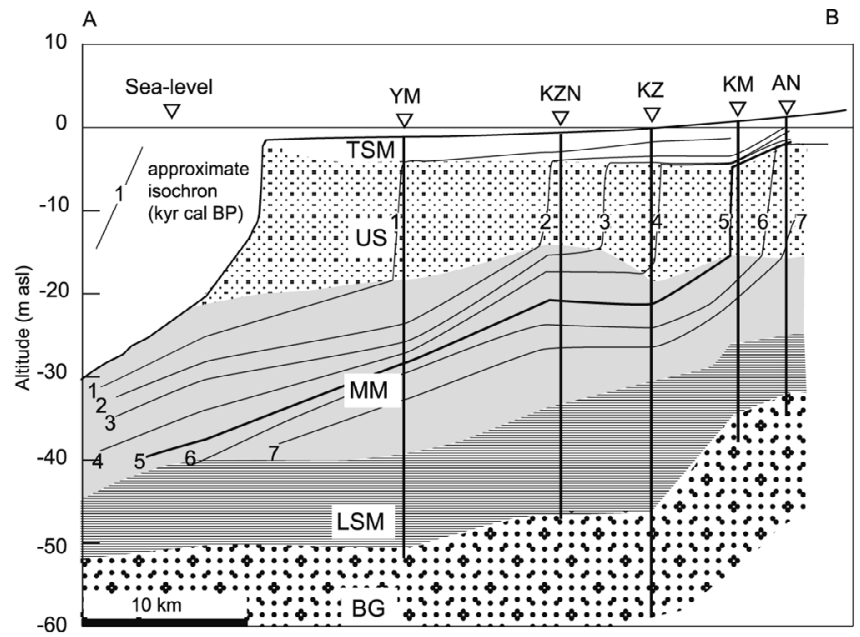

B

図 3 濃尾平野西部の模式的な地質断面図 ボーリングの位置および投影軸（A-B）は図 1 に示す. $\mathrm{YM}, \mathrm{KZN}, \mathrm{KZ}, \mathrm{KM}$ の各コアの US/ $\mathrm{MM}$ 境界以深の堆積層と等時間面は大上ほか （2009）を参照した。 AN コアの US/MM 境界 以深の堆積層は大上（2009）を参照した。

Fig. 3 Schematic Geologic cross-section of the western Nobi Plain.

The locations of cores and projection line $(\mathrm{A}-\mathrm{B})$ are shown in Fig. 1. For the cores (YM, KZN, $\mathrm{KZ}$, and KM), sedimentary facies below the US/ MM boundary and isochrones are from Ogami et al. (2009). For the AN core, sedimentary facies below the US/MM boundary are from Ogami (2009).
られる。洪水が原因であればコア掘削地点には通 常時よりも多量の淡水が流入したはずであるが, それでは EC が高くなることを説明できない（丹 羽ほか, 2009)。したがって，デルタフロント堆 積物の細粒化の原因として, 掘削地点が一時的に 堆積物の供給源から遠くなったことが考えられ る。このプロセスは次のように説明される。

すなわち，海面下のデルタフロントでは，河口 が近づくにつれて上方粗粒化する地層が堆積し, 河川の影響が強まるに従って EC 值は下がりつつ あった（図 4a）。一時的な相対的海水準上昇によ り，海岸が内陸に入り込んだ結果，コア掘削地点 が河口から遠ざかることになり，粗粒物質が供給 されにくくなると同時に海水の影響が強まって $\mathrm{EC}$ 值が高い地層が堆積した（図 4b)。その後再 びデルタが前進して河口が近づくにつれて，次第 に上方に粗粒で，ECが低い地層が堆積した（図 4c)。

\section{3）放棄チャネル堆積物の高 EC 值}

$\mathrm{KM}$ コアの深度 $7.41 \sim 5.43 \mathrm{~m}$ (図 $2 \mathrm{~b}$ の III ) に認められる放棄チャネル堆積物は, 上下の地層 との位置関係から陸上で堆積したと考えられるに もかかわらず, $\mathrm{EC}$ が $2.6 〜 3.7 \mathrm{mS} / \mathrm{cm}$ を示し海 水環境を示唆する。この $\mathrm{EC} の 一$ 時的な上昇に は，次のようなプロセスが考えられる（図 5)。

デルタの前進によって陸化した KM コア掘削
地点では，河道変化によって河道が放棄された (図 $2 \mathrm{~b}$ の $\mathrm{CH}$ から $\mathrm{CF} へ$ の岩相変化, 図 $5 \mathrm{a}$ )。当 時の海面高度は, チャネル堆積物の下位の干潟堆 積物の高度付近であったと推定される。一時的な 相対的海水準の上昇により放裹された河道の澪筋 に海水が侵入した（図 $2 \mathrm{~b}$ の境界面吕を挟んだ $\mathrm{EC}$ の上昇, 図 $5 \mathrm{~b})$ 。その結果, $\mathrm{EC} の$ 高い地層 が堆積した。その後, コア地点が陸化するまで ECの高い地層が堆積し続けた（図 5c）。

\section{4）境界面 I 〜 V 挟んで認められる相対的海 水準上昇イベントの年代}

境界面 $\mathrm{I} \sim \mathrm{N}$ を挟んだ相対的海水準の上昇を示 唆する 5 つのイベントについて，その年代を検 討する（図 6)。以降，境界面 $\mathrm{I} \sim \mathrm{V}$ を挟んで認 められる相対的海水準上昇イベントをイベント I 〜Vと呼ぶことにする。

$\mathrm{KZ}$ コアで得られた較正年代は DF1 で 3868$4241 \mathrm{cal} \mathrm{BP}, \mathrm{DF} 2$ 下部で 3828-4151 cal BP で あるので，イベント I は 4200 年前から 3800 年 前の間に起こったと考えられる。

$\mathrm{KM}$ コアの DF1の較正年代が 5320-5592 cal BP, DF2 下部の較正年代が 4764-5059 cal BP であることから，イベント II は，5600 年前から 4700 年前の間に起こったと推定される。KM コ アの CF で認められるイベント III は, DF2 最上 部の較正年代（3965-4297 cal BP） と BS の較 
(a) Before rapid relative sea-level rise

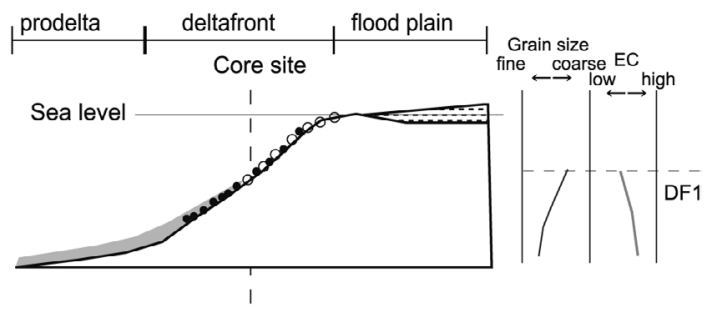

(b) Shortly after rapid'relative sea-level rise

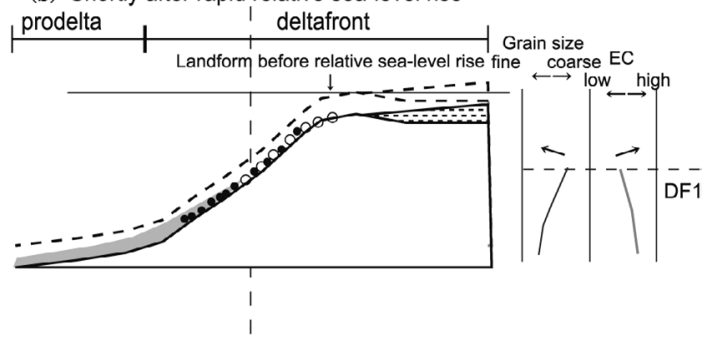

(c) After rapid relativel sea-level rise
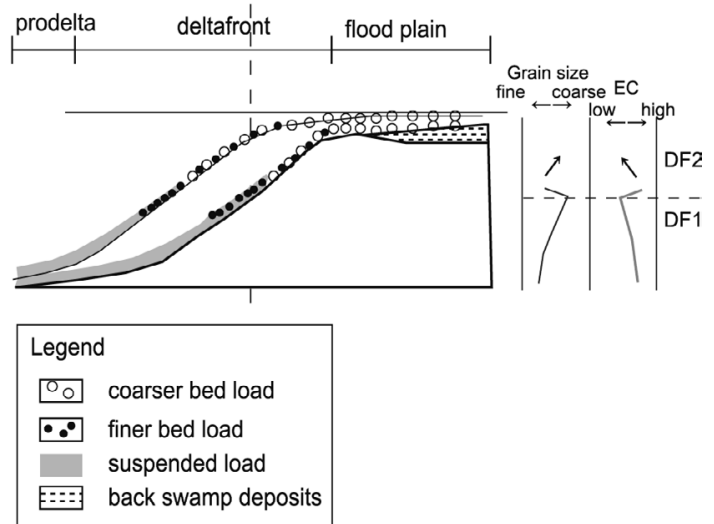

図 4 急激な相対的海水準上昇を反映した木曽川デ ルタの発達の堆積モデル.

左図は模式的なデル夕の地形・地質断面を，右図は コア地点（左図のCore site）に打ける粒径と EC の模 式的な鉛直変化とそれに対応する堆積ユニットを示す. a. 相対的海水準上昇が起こる前; b. 相対的海水準上 昇が起こった直後；c. 相対的海水準上昇が起こった後．

Fig. 4 A sedimentary model explaining the development of the Kiso River delta reflecting rapid relative sea-level rise.

The left figure shows a schematic geologic cross-section of the delta. The right figure shows vertical change of grain size and EC and sedimentary facies in the core site of the left figure. a. Before rapid relative sea-level rise; $b$. Shortly after rapid relative sea-level rise; c. After rapid relative sea-level rise.
正年代（1050-1293 cal BP） から，4300 年前か ら 1000 年前の間に起こったと考えられる。

AN コアで認められるイベント IV は，DF1の 較正年代 (5313-5576 cal BP) と DF2 から得ら れた較正年代 $(4242-4572 \mathrm{cal} \mathrm{BP})$ から， 5600 年前から 4200 年前の間に起こったと考えられる。 AN コアで認められるイベント Vは, DF2 最上 部の構成年代（4305-4615 cal BP） と GC で得 られた構成年代 $(1896-2143 \mathrm{cal} \mathrm{BP})$ から, 4600 年前から 1900 年前の間に起こったと考え られる。境界面 $\mathrm{V}$ の直下で得られた較正年代 (4305-4615 cal BP) を考慮すると，イベント V は 4600 年前よりもやや後に起こった可能性が高 い。

イベント II とイベントIVは年代的に近く，同一 の相対的海水準上昇イベントを表している可能性 が高い。イベントVは年代推定に不確実な部分が 残るが，イベント I と同じ時期に起こった可能性 がある。以上から，濃尾平野西部では海水が一時 的に進入するイベントの発生が約 $5600 \sim 4700$ 年前と 4600 〜 3800 年前に推定される。

\section{5）相対的海水準上昇イベントの原因}

上述のように，デルタフロント堆積物の一時的 な細粒化と放棄チャネル堆積物の高 EC 值は相対 的海水準上昇を示すと考えられる。この現象が完 新世後半に活断層の下盤側の低地で起こったこと を考慮すると，その原因として（1）沉世界的な 海水準変動, (2) ハイドロアイソスタシー, (3) 地盤の圧密沈下，(4) デルタの地震沈降が想定 される。

汎世界的な海水準は, 完新世後半には水床から 離れた中緯度地域では一般に低下傾向であったと され, 瀬戸内海東部の海水準変動を研究した佐藤 （2008）も，6000-1000 cal BP にかけては海面 が低下傾向にあったことを示している。また，八 イドロアイソスタシーの影響も完新世中期から後 期にかけては海水準を低下させる傾向を示す (Nakada et al., 1991)。したがって，今回見いだ された海面上昇の説明として不十分である。

圧密沈下については正確な見積もりが難しい が，地下水揚水規制後（昭和 60 年以降）の累積 

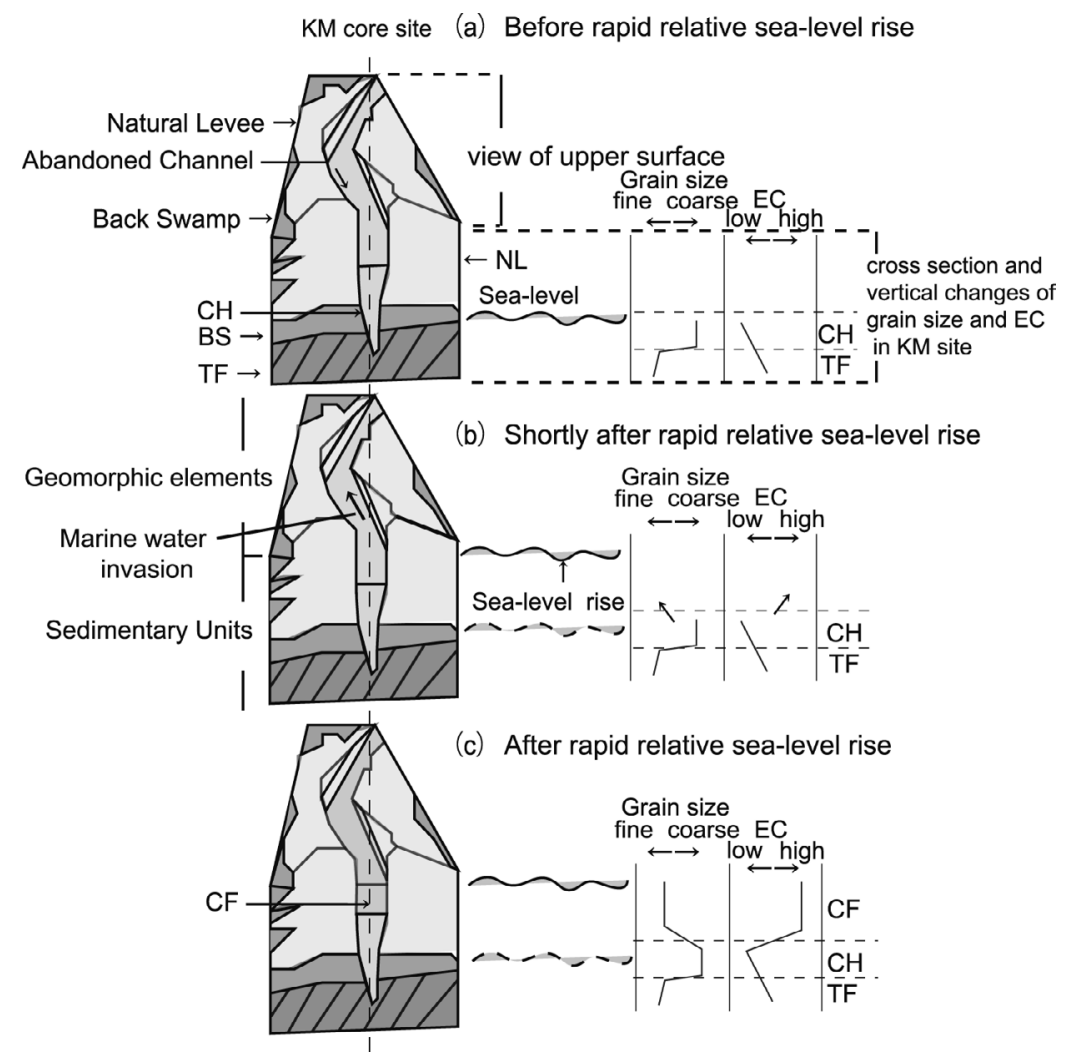

図 5 急激な相対的海水準上昇を反映した放棄チャネルへの海水の侵入の堆積モデル.

左図は模式的な氾濫原の微地形と地質断面（山口ほか, 2006b）を，右図は KM コア地点における粒径と EC の模式的な鉛直変化とそれに対応する堆積ユニットを示す. a. 相対的海水準上昇が起こる前; b. 相対的海水 準上昇が起こった直後； c. 相対的海水準上昇が起こった後.

Fig. 5 A sedimentary model explaining marine water invasion in abandoned channel reflecting rapid relative sealevel rise.

The left figure shows micro-topography and schematic geologic cross-section of the flood plain (Yamaguchi et al., $2006 \mathrm{~b})$. The right figure shows vertical change of grain size and EC and sedimentary facies in the KM core site of the left figure. a. Before rapid relative sea-level rise; b. Shortly after rapid relative sea-level rise; c. After rapid relative sea-level rise.

沈下量は濃尾平野のほとんどの地点で数 $\mathrm{cm}$ オー ダーと見積もられている（東海三県地盤沈下調査 会, 2009)。この值は本研究で検出された急激な 相対的海水準上昇を説明するには小さすぎる。ま た，圧密による地盤沈下は継続的であることから も急激な相対的海水準上昇の原因として可能性は 低い。

地震沈降については, 約 1200 年前と約 500 年 前に濃尾平野西部で急激な相対的海面上昇が起 こったこと, それらの原因として 2 回の歴史地
震 $(\mathrm{AD} 745$ 年天平地震 $\cdot \mathrm{AD} 1586$ 年天正地震 $)$ 時の養老断層系の活動による地震沈降の可能性が 高いことが報告されている（丹羽ほか, 2009）。 地震沈降であれば，急激な層相変化・粒度の細粒 化・ECの上昇とイベントの同時性を説明するこ とができる。 5600 ～ 4700 年前，および 4600 ～ 3800 年前に地震沈降が濃尾平野西縁に発生し, 相対的海水準上昇をもたらしたと考えることが もっとも合理的である。 


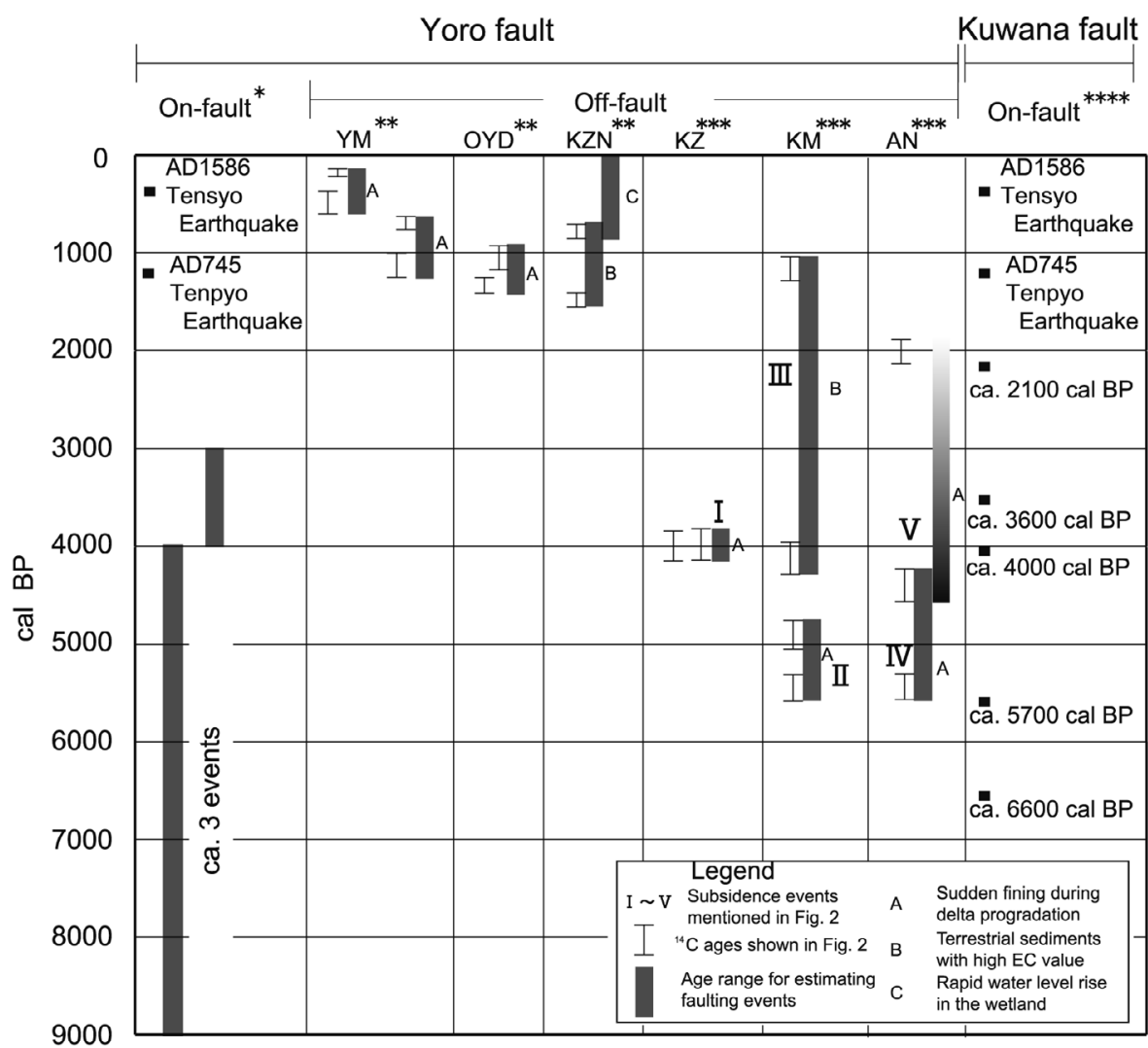

* Evidence for faulting events of Yoro fault identified by Sugai et al. (1999)

** Evidence for coseismic subsidence identified by Niwa et al. (2009)

*** Evidence for coseismic subsidence identified by this study

****Evidence for faulting events of Kuwana fault identified by Sugai et al. (1998) and Naruhashi et al. $(2004,2008)$

図 6 養老断層系の活動イベントの時空間ダイアグラム.

左端のコラムは養老断層の活動イベントの時期を，コア名（YM，OYD，KZN，KZ，KM， AN）のコラムは 養老断層の活動に起因する可能性のある沈降イベントの年代推定幅を，右端のコラムは既往研究で推定さ れた桑名断層の活動イベントの時期をそれぞれ示す。

Fig. 6 Space-time diagram of the Yoro fault system.

Columns of YM, OYD, KZN, KZ, KM, and AN show age ranges of subsidence events from faulting of the Yoro fault, whereas the leftmost and rightmost columns show faulting at the Yoro and Kuwana faults, respectively.

\section{6）養老断層系の活動と活動セグメント}

地震沈降の原因としては，養老断層系をはじめ とする調査地域周辺の活断層による断層活動があ げられる。図 6 に今回見出した地震沈降イベン トと養老断層系で認められた既報の地震イベント を整理した。養老断層では $\mathrm{AD} 745$ 年天平地震と $\mathrm{AD} 1586$ 年天正地震で活動が推定されているほ か， 約 $4000 \sim 3000$ 年前に 1 回，約 $9000 \sim$ 4000 年前に約 3 回の断層活動が推定されている
(須貝ほか, 1999)。

4600 ～ 3800 年前のイベント I と V は，養老 断層で推定された約 $4000 \sim 3000$ 年前の活動, あるいは約 $9000 \sim 4000$ 年前の約 3 回の活動の いずれかと対比されそうである（図 6)。また, イベント I とVは桑名断層で推定された約 4000 年前の活動（Naruhashi et al., 2008） とも年代 的に近い（図 6)。5600 4700 年前に推定され るイベント II と IV は，養老断層で推定された約 
$9000 \sim 4000$ 年前の約 3 回の活動のうちいずれ かと対比可能であり, また, 桑名断層で推定され た約 5700 年前の活動（Naruhashi et al., 2008） とも年代的に近い（図 6)。4300～1000 年前に 推定されるイベント III は，年代推定幅が広すぎ て，既知のイベントと対比することが現時点では 難しい。

以上から，本研究で検出された時代の異なる 2 つの地震沈降イベントは, 養老断層の活動と矛盾 しない時期に発生しており，養老断層の活動に起 因する可能性が高い。また，イベント I と V（約 $4600 ３ 800$ 年前）とイベント II と IV（約 5600 〜 4700 年前）は桑名断層の活動時期に対比され る。これらのことから, 養老断層の活動として新 たに知られた 2 つの地震イベントの発生時期は 桑名断層の活動時期に対応するものであり，養老 断層と桑名断層が同時に活動を繰り返してきた可 能性が推定される。桑名断層の活動として知られ る約 2100 年前のイベントも養老断層のイベント IIIに対比される可能性（図 6）を考慮すると，そ れぞれが独立して活動した記録は認められなくな る。すでに，須貝ほか（1999）は AD 745 年天 平地震, $\mathrm{AD} 1586$ 年天正地震の際, 養老断層と 桑名断層が同時に活動した可能性を指摘してい る。今回の古地震対比の結果からみても養老・桑 名断層はこれまで同時に活動した可能性が高く, 両断層が同一の活動セグメントをなすと考えるこ とが妥当である。

\section{VI. まとめ}

養老断層下盤側（沈降側）に位置する濃尾平野 で掘削された 3 本のボーリングコアの解析に基 づいて, 同断層の完新世における活動の痕跡を検 出することを試みた。その結果以下のことが明ら かになった。

1. 養老断層からやや離れた地点の堆積環境の 復元から広域的に起こった沈降イベントを認定し た。

2. デルタフロント堆積物で水深増加と河口か らの距離の増大を示す一時的な細粒化と EC 值の 増加が約 $4700 \sim 5600$ 年前には $\mathrm{KM}$ コアと $\mathrm{AN}$
コアで，4600〜 3800 年前には $\mathrm{KZ}$ コアと $\mathrm{AN}$ コアで認められた。また, 岩相から陸上堆積を示 唆する放棄チャネル堆積物で海水の侵入を示す高 $\mathrm{EC}$ 值が $4300 \sim 1000$ 年前に KM コアで認めら れた。これらは一時的な相対的海水準上昇が起 こった可能性を示し, その原因として地震沈降が あげられる。

3. 上記 2 回ないし 3 回の地震沈降は養老断層 の活動に起因する可能性が示唆され, ${ }^{14} \mathrm{C}$ 年代に 基づくと, これらすべての活動が養老断層の南側 に位置する桑名断層の活動と同時に起こったと考 えても矛盾しない。

4. この地震イベントの対比が正しければ, 養 老断層と桑名断層は同一の活動セグメントをなす 可能性が高い。

\section{謝 辞}

本研究を進めるにあたって, 松島紘子氏, 三枝芳江 氏, 若林 徹氏をはじめとする東京大学大学院新領域 創成科学研究科自然環境学専攻の院生諸氏, 中央大学 理工学部の吉田英嗣博士にはさまざまなご議論をいた だいた。核燃料サイクル開発機構（現日本原子力研究 開発機構) 東濃地科学センターのペレトロン担当スタッ フの方々には年代測定に際して便宜を図っていただい た。本研究では，核燃料サイクル開発機構（現日本原 子力研究開発機構) 東濃地科学センター, 地質調查所 (現産業技術総合研究所活断層・地震研究センター) に よって掘削されたボーリングコアの一部を使用させて いただいた。本稿は匿名の查読者のご指摘・助言に よって改善された。以上の方々に深く感謝致します。

\section{文献}

粟田泰夫・吉田史郎（1991）: 桑名断層掞よび四日市断 層の完新世における活動. 活断層研究，9，61-68.

Hughen, K.A., Baillie, M.G.L., Bard, E., Beck, J.W., Bertrand, C.J.H., Blackwell, P.G., Buck, C.E., Burr, G.S., Cutler, K.B., Damon, P.E., Edwards, R.L., Fairbanks, R.G., Friedrich, M., Guilderson, T.P. Kromer, B., McCormac, F.G., Manning, S.W., Bronk Ramsey, C., Reimer, P.J., Reimer, R.W., Remmele, S., Southon, J.R., Stuiver, M., Talamo, S., Taylor, F.W., van der Plicht, J. and Weyhenmeyer, C.E. (2004): Marine04 Marine radiocarbon age calibration, 26-0 ka BP. Radiocarbon, 46, 1059-1086.

飯田汲事 (1987): 天正大地震誌. 名古屋大学出版会, $552 \mathrm{p}$. 
池田安隆 - 今泉俊文 - 東郷正美 - 平川一臣・宮内崇裕 · 佐藤比呂志編 (2002): 第四紀逆断層アトラス. 東京 大学出版会, $260 \mathrm{p}$.

井関弘太郎 (1962): 沖積平野研究の基礎的問題点. 名 古屋大学文学部研究論集, 26, 51-74.

Ishiyama, T., Mueller, K., Sato, H. and Togo, M. (2007): Coseismic fault-related fold model, growth structure, and the historic multisegment blind thrust earthquake on the basement-involved Yoro thrust, central Japan. Journal of Geophysical Research, 112, B03S07, doi:10.1029/2006JB004377.

地震調査研究推進本部 (2010): 今までに公表した活断 層及び海溝型地震の長期評価結果一覧. 地震調査研 究推進本部, $13 \mathrm{p}$.

貝塚爽平 $(1950)$ : 桑名市西部の断層地形. 地理学評論, 22, 352-356.

活断層研究会 (1980): 日本の活断層一分布図と資料. 東京大学出版会, 363p.

活断層研究会 (1991): 新編日本の活断層一分布図と資 料. 東京大学出版会, $437 \mathrm{p}$.

桑原 徹 (1968): 濃尾盆地と傾動地塊運動. 第四紀研 究, 7, 235-247.

MaCalpin, J. (1996): Application of paleoseismic data to seismic hazard assessment and neotectonic research. in Paleoseismology edited by MaCalpin, J., Academic Press, 439-493.

MaCalpin, J. and Nelson, A.R. (1996): Introduction to paleoseismology. in Paleoseismology edited by MaCalpin, J., Academic Press, 1-28.

松田時彦・太田陽子・岡田篤正・清水文健 - 東拫正美 (1977): 空中写真による活断層の認定と実例。地震研 究報, 52, 461-496.

Nakada, M., Yonekura, N. and Lambeck, K. (1991): Late Pleistocene and Holocene sea-level changes in Japan: Implications for tectonic histories and mantle rheology. Palaeogeography, Palaeoclimatology, Palaeoecology, 85, 107-122.

鳴橋龍太郎 · 須貝俊彦・藤原 治 - 粟田泰夫 (2004): 完新世浅海堆積物の堆積速度の変化から見た桑名断 層の活動間隔. 第四紀研究，43，317-330.

Naruhashi, R., Sugai, T., Fujiwara, O. and Awata, Y. (2008): Detecting vertical faulting event horizons from Holocene sym-faulting in shallow marine sediments on the western margin of the Nobi plain, central Japan. Bulletin of the Seismological Society of America, 98, 1447-1457.

丹羽雄一 - 須貝俊彦 - 大上隆史 - 田力正好 - 安江健一 . 齋藤龍郎・藤原 治 $(2009)$ : 濃尾平野西部の上部完 新統に残された養老断層系の活動による沈降イベン 卜. 第四紀研究，48，339-349.

大上隆史 (2009): 濃尾平野における最終水期以降の相 対的海水準変動に伴う堆積体発達過程. 東京大学大 学院新領域創成科学研究科自然環境学専攻博士論文, $123 p$.

大上隆史・須貝俊彦 (2006) : 後期更新世以降における 四日市断層の活動性評価. 第四紀研究，45，131139.
大上隆史・須貝俊彦・藤原 治 - 山口正秋 - 笹尾英嗣 (2009): ボーリングコア解析と ${ }^{14} \mathrm{C}$ 年代測定にもとつ く木曽川デルタの形成プロセス. 地学雑誌, 118, 665-685.

Ohmori, H. (1983): Erosion rates and their relation to vegetation from the viewpoint of world-wide distribution. Bulletin of the Department of Geography, University of Tokyo, 15, 77-91.

岡田篤正 (1979): 活断層一愛知県と周辺地域における 活断層と歴史地震一. 愛知県防災会議地震部会, $102 p$.

太田陽子 - 寒川 旭 (1984): 鈴鹿山脈東麓地域の変位 地形と第四紀地殼変動. 地理学評論, 57A, 237262.

Reimer, P.J., Baillie, M.G.L., Bard, E., Bayliss, A., Beck, J.W., Bertrand, C.J.H., Blackwell, P.G., Buck, C.E., Burr, G.S., Cutler, K.B., Damon, P.E., Edwards, R.L., Fairbanks, R.G., Friedrich, M., Guilderson, T.P., Hogg, A.G., Hughen, K.A., Kromer, B., McCormac, F.G., Manning, S.W., Ramsey, C.B., Reimer, R.W., Remmele, S., Southon, J.R., Stuiver, M., Talamo, S., Taylor, F.W., van der Plicht, J. and Weyhenmeyer, C.E. (2004): IntCal04 Terrestrial radiocarbon age caliblation, $26-0$ ka BP. Radiocarbon, 46, 1029-1058.

佐藤裕司 (2008): 瀬戸内海東部, 播磨灘沿岸域におけ る完新世海水準変動の復元.第四紀研究，47，247259.

Stuiver, M. and Reimer, P.J. (1993): Extended 14Cdatabase and revised CALIB radiocarbon calibration program. Radiocarbon, 35, 215-230.

須貝俊彦・杉山雄一 (1999): 深層ボーリング (GSNB-1）と大深度地震探査に基づく濃尾傾動盆地の沈 降・傾動速度の総合評価. 地質調査所速報, EQ/99/3, 69-76.

須貝俊彦・杉山雄一・松本則夫 ·佃 栄吉 (1998): 深 層オールコアボーリングの解析による養老断層の活 動性調査．地質調査所速報，EQ/98/1，67-74.

須貝俊彦・伏島祐一郎・粟田泰夫 ·吾妻 崇・苅谷 愛彦・鈴木康弘 (1999): 養老断層の完新世後期の活 動履歴一 1586 年天正地震 $\cdot 745$ 年天平地震震源断層 の可能性. 地質調査所速報, EQ/99/3, 77-87.

高田康秀・近藤善教・宮村 学 (1979): 津島地域の地 質. 地域研究報告 (5 分の 1 地質戝幅), 地質調査所, $56 \mathrm{p}$.

東海三県地盤沈下調査会 (2009): 平成 20 年における 濃尾平野の地盤沈下の状況. 東海三県地盤沈下調査 会, $71 \mathrm{p}$.

内園立男・森 勇一 (2004): 濃尾平野南部ボーリング コアの粘土混濁水の電気伝導度および $\mathrm{pH}$ 測定に基 づく堆積環境の推定. 第四紀研究，43，375-382.

海津正倫 (1992): 木曽川デル夕における沖積層の堆積 過程. 堆積学研究会報, 36, 47-56.

宇佐美龍夫（1996）: 新編日本被害地震総覧. 東京大学 出版会, 493p.

山口正秋 · 須貝俊彦 · 太田 剛 - 大森博雄 - 杉山雄一 . 藤原 治 (2001): ボーリングコアの総合解析にもと 
づく濃尾平野の堆積環境の推定. 日本地理学会発表 要旨集, 60, 90 .

山口正秋 ·須貝俊彦 ·藤原 治 ·鎌滝孝信 · 大森博雄 · 杉山雄一 (2003): 濃尾平野ボーリングコア解析にも とづく完新統の堆積過程. 第四紀研究, 42, 335346 .

山口正秋 ·須貝俊彦 ·藤原 治 - 鎌滝孝信 · 大森博雄 · 杉山雄一 (2005): ボーリングコアの粒度組成と堆積 速度からみた木曽川デルタの微地形と堆積過程. 第 四紀研究，44，37-44.

山口正秋 ·須貝俊彦 - 大上隆史 - 藤原 治 - 大森博雄 (2006a): 高密度ボーリングデー夕解析にもとづく濃 尾平野沖積層の三次元構造. 地学雑誌, 115, 4150.

山口正秋 ·須貝俊彦 - 藤原 治 · 大上隆史 · 大森博雄 (2006b): 木曽川デルタにおける沖積最上部層の累重 様式と微地形形成過程. 第四紀研究, 45, 451-462. 山崎晴雄・衣笠善博・佐竹健治 (2004): オフ・フォー ルト・パレオサイスモロジーの意義と必要性. 日本 地球惑星科学連合 2004 年大会予稿集 (CD-ROM), J063-001.

横山卓雄・佐藤万寿美 (1987): 粘土混濁水の電気伝導 度による古環境の推定一千里山丘陵東端部および琵 琶湖湖底におけるボーリング・コアの場合一。地質 学雑誌, 93, 667-679.

吉田史郎 (1984): 四日市地域の地質。地域地質研究報 告 (5 分の 1 図幅). 地質調査所, $154 \mathrm{p}$.

(2009 年 10 月 16 日受付, 2010 年 5 月 17 日受理) 